\title{
A framework for site assessment guides for urban impacted soils: A Vancouver case study
}

\author{
Melissa Iverson, ${ }^{a}$ Maja Krzic, ${ }^{a *}$ and Arthur Bomke ${ }^{a}$ \\ University of British Columbia, Vancouver
}

Submitted December 2, 2013 / Revised May 22 and July 14, 2014 / Accepted July 14, 2014 /

Published online November 21, 2014

Citation: Iverson, M., Krzic, M., \& Bomke, A. (2014). A framework for site assessment guides for urban impacted soils: A Vancouver case study. Journal of Agriculture, Food Systems, and Community

Development, 5(1), 75-85. http://dx.doi.org/10.5304/jafscd.2014.051.006

Copyright (C) 2014 by New Leaf Associates, Inc.

\begin{abstract}
Urban agricultural activities, such as community gardening and urban farming, are becoming popular in many North American cities, including Vancouver, British Columbia (BC). Currently, demand for urban agricultural land in Vancouver is mainly met by reclaiming brownfields (vacant and often neglected tracts of land) and land owned or managed by schools, religious institutions, hospitals, and private residents, into gardens and urban farms. Before urban sites can be reclaimed, they need to be assessed for suitability for food production; however, many cities, including
\end{abstract}

\footnotetext{
${ }^{a}$ Faculty of Land and Food Systems, University of British Columbia, Vancouver, British Columbia V6T 1Z4 Canada.

* Corresponding author: Maja Krzic, Associate Professor, Faculty of Land and Food Systems, University of British Columbia;

2357 Main Mall; Vancouver, British Columbia V6T 1Z4

Canada; +1-604-822-0252; maja.krzic@ubc.ca
}

Vancouver, do not have locally adapted site assessment guides (SAGs). This paper describes the development of a framework for a SAG for Vancouver soils. The framework consists of the following five phases: (1) initial selection of properties and assessment approaches; (2) stakeholder feedback and subsequent revision of the properties identified in Phase 1; (3) additional feedback, revision, and finalization of the SAG; (4) distribution of the guides; and (5) ongoing updates and support. As part of framework development, we identified relevant site characteristics (e.g., soil properties, aspect, slope, amount of sunshine) for Vancouver and developed a Vancouver soil map. Distribution and promotion of the SAG through local organizations and societies started in 2010, and ongoing efforts regarding these initiatives are underway. The SAG framework used in Vancouver may be useful to other cities that wish to empower their citizens to create spaces for urban agriculture safely and successfully. 


\section{Keywords}

urban soil, brownfields, community gardens, urban agriculture, site assessment, soil quality

\section{Introduction}

At present, half the world's population lives in cities, and according to some projections two out of every three people will be city-dwellers by the year 2030 (Hynes \& Howe, 2004). The increasingly urbanized general public has a limited understanding of the food system, as food is often grown thousands of kilometers away (Brown, 2009). Urban agriculture offers opportunities for citizens to become aware of, and engage in, overall food issues. Many cities around the world are experiencing an increase in the popularity of community gardens and urban farms (Turner, Henryks, \& Pearson, 2011). These gardens and farms are commonly developed on urban brownfields (i.e., vacant tracts of marginalized land that are in derelict condition due to neglect and are thought to be contaminated) (De Kimpe \& Morel, 2000) as well as on parks and land owned or managed by schools, religious institutions, hospitals, and private residents. In order for these gardens and farms to thrive, knowledge of the soils on these lands is essential (Hazelton \& Murphy, 2011).

Urban farms and community gardens provide many benefits to city-dwellers. Here we have defined the term "community garden" as a garden that has been developed on land to which communities have legally been granted access and have a governance system and a structure (either allotment or communal) that has been decided and agreed upon by the community, and we have defined "urban farm" as a food-growing commercial enterprise located within a city's limits. Community gardens and urban farms provide local sources of produce that has not traveled long distances using large amounts of fossil fuels; they also provide spaces that allow citizens to strengthen social interactions, encourage physical activity, beautify the neighborhoods, and much more (Alaimo, Reischl, \& Allen, 2010). Community gardens and urban farms also provide opportunities for people to learn how to grow food. People who grow their own food not only have better access to fresh produce, but are also more likely to adopt a healthier diet (Alaimo, Packnett, Miles, \& Kruger, 2008).

Some larger Canadian cities struggle to find available land for community gardens and urban farms. In Toronto and particularly in Vancouver an expansion of urban agriculture is occurring mainly on brownfields (Kaethler, 2006; Patel \& MacRae, 2012), although it also occurs on land owned or managed by schools, religious institutions, hospitals, and private residents. In Vancouver, brownfields are prevalent because they exist on land that (a) has not yet been developed; (b) once was occupied by structures that have since been torn down; or (c) is on a right-of-way, such as the area adjacent to the railway or under the SkyTrain, Vancouver's rapid transit system. Whatever the origin, underutilized urban land, which can collect litter and lower community morale, can serve as a valuable resource to cities and their citizens if they can be reclaimed into spaces for urban agriculture.

Those interested in starting urban farms and community gardens face certain hurdles, including the task of addressing the soil-quality issues of their potential farm or garden sites. Soil compaction, contamination, and low fertility are common issues on urban soils, limiting their suitability for gardening. These issues underscore the importance of site assessment protocols for urban soils that are to be reclaimed into community gardens or urban farms (De Kimpe \& Morel, 2000; Hazelton \& Murphy, 2011). For example, Toronto Public Health (2013) has developed the Guide for Soil Testing in Urban Gardens that provides advice on the decisionmaking process in relation to soil contamination, including whether or not to test the soil.

A valuable example of how to address the challenge of assessing urban soils on sites intended for urban agriculture can be found in the process of developing "Soil Quality Cards" or "Soil Health Cards" for agricultural land in the U.S. (Romig, Garlynd, Harris, \& McSweeney, 1995). "Soil Quality Cards" are qualitative assessment tools that have been used by U.S. farmers since early 1990 s to evaluate the current status of soil quality and, when used over time, to determine changes in soil quality that are affected by land management. As outlined by Tugel, Seiter, Friedman, Davis, Dick, McGrath, \& Weil (2001) "Soil Quality Cards" need to be: (1) 
locally adapted; (2) developed through participatory partnerships among farmers, scientists, and extension specialists; and (3) simple and user-friendly. An assessment tool possessing these three characteristics, altered to be relevant to the urban environment, would empower urban farmers and community gardeners to safely and successfully grow food within city limits.

The rapid development of community gardens and urban farms that the city of Vancouver experienced in the early 2000s (City of Vancouver, 2013) highlighted the fact that the city did not have a user-friendly protocol to aid the conversion of various types of land, including brownfields, into land for food production. Consequently, stakeholders were burdened with the challenge of determining how to approach site assessments on their own. The objective of this study was to develop a framework for a locally adapted site assessment guide (SAG) for urban impacted soils that are to be reclaimed for urban agriculture, using Vancouver as a case study. The SAG is useful for all urban impacted soils, but its relevance is the greatest for brownfield soils due to their high probability of contamination and low soil quality.

\section{Methodology and the Vancouver Study Case}

\section{Project Principles}

Drawing from the process of developing "Soil Quality Cards" (Ditzler \& Tugel, 2002; Tugel et al., 2001) carried out by the Soil Quality Institute of the United States Department of Agriculture, Natural Resources Conservation Service (USDANRCS), we approached the development of the SAG by using the principles of soft systems inquiry, community-based action research, and locally led urban environmentalism.

Understanding the views and values of community stakeholders is an integral component of the SAG-creation process. Direct stakeholder involvement ensures that the SAG is tailored to the needs of a particular community or region. A soft systems inquiry approach focuses on exploring these views and values (Checkland \& Scholes, 1999). We used a community-based action research approach (Stringer, 1999) while conducting workshops and seeking additional stakeholder feedback.
This approach promotes participant-led workshop facilitation techniques, where facilitators and participants are seen as equal partners during educational exchanges. By conducting learner-centered interactive workshops with community gardening groups, the project team was able to identify common areas of concern and interest expressed by community stakeholders.

Locally led urban environmentalism is based on the principle that local communities possess the specialized knowledge necessary to identify and resolve local environmental issues (Tugel et al., 2001). Each city will present its own unique set of environmental challenges. By informing the project team of these specific environmental issues, local stakeholders provide the focus for the SAG, allowing their needs to be better addressed.

\section{Case Study: Vancouver}

The city of Vancouver is located on the western half of the Burrard Peninsula, bordered to the north by English Bay and the Burrard Inlet and to the south by the Fraser River. With its population of 603,502 (according to the 2011 census)

Vancouver is the largest city in B.C. and the eighth largest in Canada (City of Vancouver, 2013a). ${ }^{1}$ Vancouver is located on lag and littoral materials that overlie glacial till and fine textured marine, glaciomarine, and alluvial deposits, and on soils that belong to Humo-Ferric Podzols (Iverson, Holmes \& Bomke, 2012). The area is characterized by a humid, maritime climate, with warm, dry summers and mild, wet winters. Mean annual precipitation in Vancouver is $1200 \mathrm{~mm}$ (47 inches), 70 percent of which falls between October and May (Environment Canada, 2014).

Currently, there are 75 community gardens in Vancouver, which represents a 30 percent increase relative to the early 2000s (City of Vancouver, 2013b). This notable increase was enabled through an initiative to green the city (i.e., increase the number of environmental initiatives and create more green spaces) led by the municipal government, facilitating the development of 2,010 garden

\footnotetext{
1 The Greater Vancouver metropolitan area, which includes the neighboring cities of Burnaby, Richmond, and Surrey, is the third largest in Canada.
} 
plots by the time Vancouver hosted the 2010 Winter Olympics. The municipal government has also fostered urban agriculture through several other initiatives. Among these is the current Greenest City initiative, with a goal of making Vancouver a global leader in urban food systems by 2020 . Even with these priorities, the city of Vancouver had no locally adapted site assessment guides to help community gardeners and urban farmers assess sites for food-growing potential.

\section{Creating a Locally Adapted SAG for Urban Soils in} Vancouver

The framework for SAGs (Table 1) includes the following five phases: (1) initial selection of properties and assessment approaches; (2) stakeholder feedback and subsequent revision of the initial properties and approaches; (3) additional feedback, revision, and finalization of the SAG; (4) distribution of the guide; and (5) ongoing updates and support.

During the initial development of a SAG (Phase 1), a list of commonly used assessment approaches for local contaminated sites is compiled. In addition, site characteristics (e.g., soil properties, aspect, slope, amount of sunshine) that might be of relevance for SAG are identified. This helps situate the SAG in an urban context while tailoring it to the specific conditions of the local environment. Information on local soil types and properties is usually found in soil surveys and maps; however, such information often does not exist for urban areas that have been paved over long before surveys were conducted. Vancouver was not an exception; hence, as part of Phase 1 of the SAG development, we conducted a detailed inventory of soils in the Vancouver area based on the interpretation of surficial geology (Armstrong \& Hicock, 1976), elevation and topography, combined with an extrapolation of known soils series from mapped areas in the Lower Fraser Valley near Vancouver (Luttmerding, 1984) and established corresponding soil management groups (Iverson et al., 2012) for Vancouver.

The list of selected site characteristics and their methods of determination (e.g., soil texture determined through hand texturing) are presented to stakeholders to gather feedback related to clarity and feasibility (Phase 2). This approach is commonly employed as part of community-based action research (Stringer, 1999). The feedback is collected through participatory workshops. The role of the workshop facilitator is not to impose his or her own ideas, but to enable participants to make informed decisions and to assist in implementing those decisions. Based on feedback from our stakeholders (Environmental Youth Alliance, $\mathrm{n}=10$; Cedar Cottage Community Garden Society,

Table 1. The Five Phases of the Framework for the Urban Site Assessment Guide (SAG)

\begin{tabular}{|c|c|c|}
\hline Phase & Activity & Description \\
\hline 1 & $\begin{array}{l}\text { Initial selection of properties and } \\
\text { assessment approaches }\end{array}$ & $\begin{array}{l}\text { - Compile a list of site assessment approaches commonly used on local } \\
\text { contaminated sites. } \\
\text { - Identify soil and microclimate properties to be included into } \\
\text { assessment. }\end{array}$ \\
\hline 2 & $\begin{array}{l}\text { Stakeholder feedback and subsequent } \\
\text { revisions of the initial properties and } \\
\text { assessment approaches }\end{array}$ & $\begin{array}{l}\text { - Present selected soil and microclimate properties and their methods of } \\
\text { assessment to stakeholders for feedback. } \\
\text { - Revise initial selection of soil and microclimate properties based on } \\
\text { the feedback. }\end{array}$ \\
\hline 3 & $\begin{array}{l}\text { Additional feedback, revision, and } \\
\text { finalization }\end{array}$ & $\begin{array}{l}\text { - Collect a second round of stakeholder feedback and revise SAG as } \\
\text { needed. } \\
\text { - Finalize SAG. }\end{array}$ \\
\hline 4 & Distribution & $\begin{array}{l}\text { - Distribute SAG through a variety of avenues (e.g., websites of local } \\
\text { government, nongovernmental organizations, field days, workshops). }\end{array}$ \\
\hline 5 & Ongoing updates and support & $\begin{array}{l}\text { - Ensure ongoing updates of SAG by employees and/or volunteers at the } \\
\text { organizations that distribute the SAG. } \\
\text { - Support and backing provided by various groups and organizations. }\end{array}$ \\
\hline
\end{tabular}


$\mathrm{n}=5$; Sustainable Living Arts School, $n=15$ ) the project team revised the initial list of soil and microclimate indicators.

Adhering to the cyclical nature of participatory action research, a second round of stakeholder feedback is collected, allowing for additional SAG revision before finalizing the guide (Phase 3). The stakeholders who took part in the second round of feedback were community members involved in activities such as community garden development and organization, youth engagement in urban agriculture, and soil science and agriculture education.

To ensure that a SAG is accessible to a wide range of stakeholders, a variety of avenues for its distribution need to be put in place (Phase 4). Those avenues may include local environmental and urban agricultural organizations, and/or the social planning department of the city government. The Vancouver SAG is available on the websites for two local nongovernmental organizations: the Society Promoting Environmental Conservation and City Farmer. Ongoing updates are necessary and must be implemented by employees or volunteers at an organization that distributes the SAG (Phase 5).

\section{Results and Discussion}

Features of the Locally Adapted $S A G$ for V ancouver By implementing Phases 1 through 5, a SAG for urban soils in Vancouver, entitled Starting a Community Garden: A Site Assessment Guide for Communities,

\section{Figure 1. The Decision Tree from the Final Version of the Site Assessment Guide (SAG) for the City of Vancouver, British Columbia}

The chart is presented at the beginning of the SAG (Starting a Community Garden: A Site Assessment Guide for Communities) and is intended to guide users through the site assessment process.

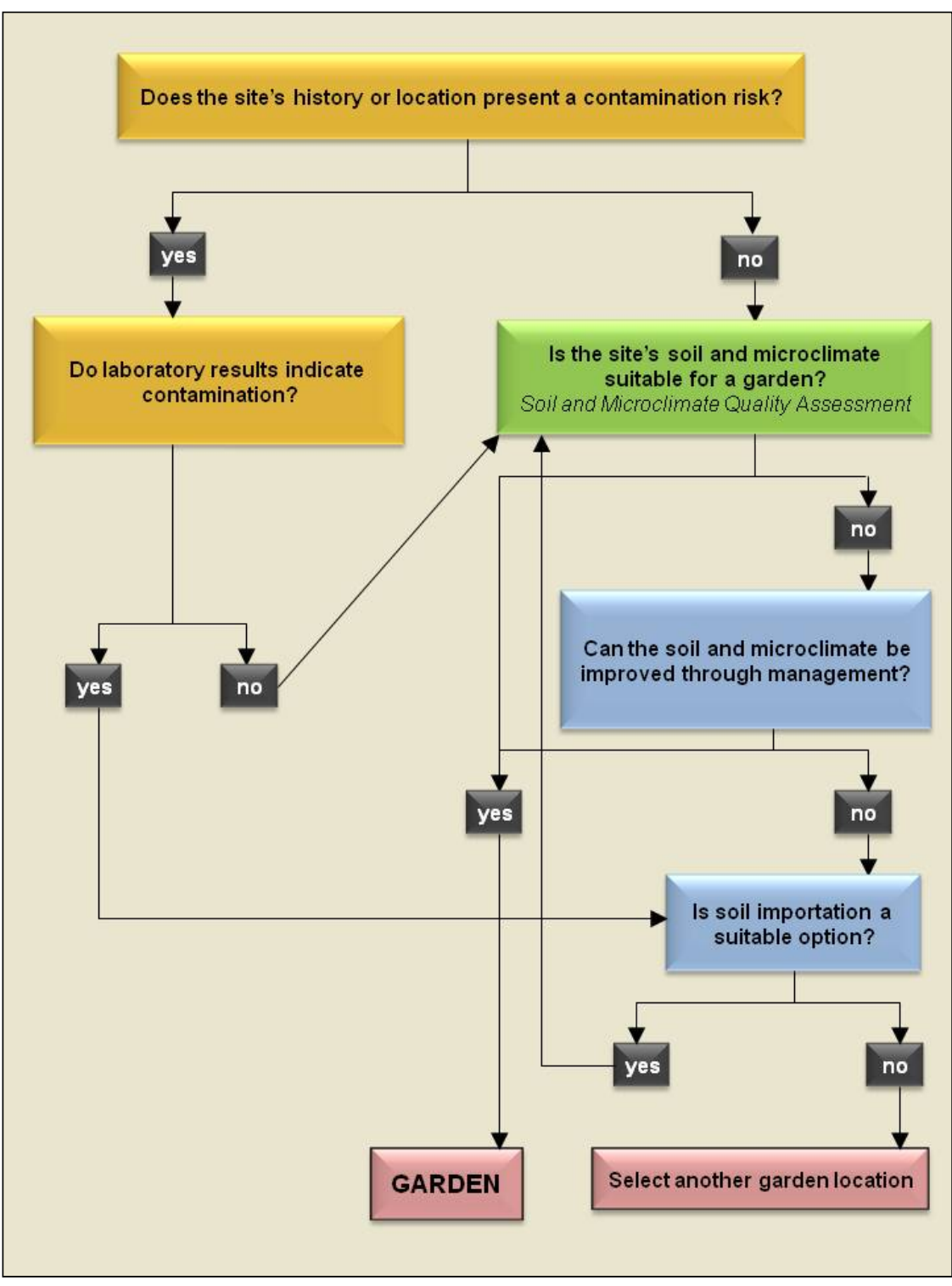

was completed in 2010. The SAG includes the following sections: (1) determining soil contamination; (2) soil and microclimate assessment; and (3) management practices and soil importation. A decision tree (Figure 1) depicts the structure of the SAG. This decision tree consists of five boxes, each containing a question or activity that users complete to determine the suitability of their site. Each question also serves as a chapter heading; the 
chapters provide users with background information and guidance on how to answer the specific question listed in the SAG decision tree. The goal of each section of the SAG is to identify barriers presented by soil contamination or inadequate soil and/or microclimate, and address them through either management practices or soil importation.

Development of the SAG (Phase 1) started by compiling a list of site characteristics of potential relevance for urban soils in general, and for Vancouver soils in particular. It is difficult to generalize about the properties of urban soils, which can vary tremendously even within a single site. The heterogeneity of urban soils is caused by the large variety of human activities and interventions that shape anthropogenic soils. Modification activities, such as soil stripping, filling, mixing, compacting, and importing or exporting of topsoil, at varying levels of

Table 2. Site Characteristics of Relevance to Urban Soil Assessment in the City of Vancouver, British Columbia

\begin{tabular}{|c|c|c|}
\hline Property & Implication for Soils & Potential Modifications by Human Activities \\
\hline $\begin{array}{l}\text { Presence of anthropogenic } \\
\text { and other contaminants }\end{array}$ & $\begin{array}{l}\text { Negatively affect drainage and aeration as } \\
\text { well as plant growth. }\end{array}$ & Remnants of past land use and/or neglect. \\
\hline $\begin{array}{l}\text { Soil texture } \\
\text { (particle size) }\end{array}$ & $\begin{array}{l}\text { Amount of clay, silt, and sand determine } \\
\text { soil's water- and nutrient-holding capacity, } \\
\text { drainage, and aeration. }\end{array}$ & $\begin{array}{l}\text { Modified by cutting and filling (especially } \\
\text { topsoil removal). }\end{array}$ \\
\hline $\begin{array}{l}\text { Coarse fragments } \\
\text { (diameter }>2 \mathrm{~mm} \text { ) }\end{array}$ & $\begin{array}{l}\text { Inherited from parent material and impact } \\
\text { cultivation, trafficability and soil volume } \\
\text { available for root growth. }\end{array}$ & $\begin{array}{l}\text { Brought closer to the surface by topsoil } \\
\text { removal. Coarse fragments are also some- } \\
\text { times removed from the soil by stone picking. }\end{array}$ \\
\hline Soil compaction & $\begin{array}{l}\text { Impacts root growth, drainage, and aeration, } \\
\text { which in turn affect activity of soil organisms. }\end{array}$ & Created by human and mechanized traffic. \\
\hline Soil structure & $\begin{array}{l}\text { Impacts pore size distribution and in turn } \\
\text { drainage and aeration. }\end{array}$ & $\begin{array}{l}\text { Destroyed by human and mechanized traffic, } \\
\text { leading to surface crust formation and } \\
\text { compaction. }\end{array}$ \\
\hline Rooting depth & Affects plant growth. & $\begin{array}{l}\text { Reduced by topsoil removal and scraping, or } \\
\text { restricted by some naturally occurring dense } \\
\text { layers. }\end{array}$ \\
\hline Soil organic matter & $\begin{array}{l}\text { Impacts soil's capability to retain water and } \\
\text { nutrients. Source of nutrients such as } \\
\text { nitrogen, sulfur, and phosphorus. }\end{array}$ & $\begin{array}{l}\text { Soil organic matter quantity and quality are } \\
\text { modified by cutting and filling (especially } \\
\text { topsoil removal). It could also be affected by } \\
\text { additions of various organic residues and } \\
\text { amendments. }\end{array}$ \\
\hline Soil reaction $(\mathrm{pH})$ & $\begin{array}{l}\text { Impacts plant growth, soil organisms, and } \\
\text { nutrient availability. }\end{array}$ & $\begin{array}{l}\text { Modified by liming, construction rubble burial, } \\
\text { and dust and ash deposition. }\end{array}$ \\
\hline Cation exchange capacity & $\begin{array}{l}\text { Soil's capability to retain and supply } \\
\text { nutrients in available forms to plants and } \\
\text { soil organisms. }\end{array}$ & $\begin{array}{l}\text { Human activities that lead to loss of organic } \\
\text { matter and extreme changes of } \mathrm{pH} \text { will } \\
\text { change cation exchange capacity and } \\
\text { interrupt nutrient cycling. }\end{array}$ \\
\hline $\begin{array}{l}\text { Soil organisms } \\
\text { (e.g., earthworms) }\end{array}$ & $\begin{array}{l}\text { Decompose organic matter and release } \\
\text { available forms of nutrients. Improve soil } \\
\text { aeration and drainage. }\end{array}$ & $\begin{array}{l}\text { Negatively affected by human activities that } \\
\text { cause contamination, compaction, loss of } \\
\text { organic matter, and extreme changes of } \mathrm{pH} \text {. }\end{array}$ \\
\hline Shading & Direct impact on plant growth. & $\begin{array}{l}\text { Caused by small lot size and presence of } \\
\text { nearby buildings; in turn reduces } \\
\text { photosynthetic radiation and ambient } \\
\text { temperatures. }\end{array}$ \\
\hline Soil temperature & $\begin{array}{l}\text { Affects plant growth and activity of soil } \\
\text { organisms, as well as soil chemical } \\
\text { reactions. }\end{array}$ & Impacted by shading of the nearby buildings. \\
\hline $\begin{array}{l}\text { Topography } \\
\text { (aspect, slope, elevation) }\end{array}$ & $\begin{array}{l}\text { Impacts soil processes such as drainage, soil } \\
\text { creep and deposition, and erosion. }\end{array}$ & Changed by scraping, cutting, and filling. \\
\hline
\end{tabular}




\section{Figure 2. Map of Vancouver, British Columbia, Indicating the Four Soil Management Groups: Delta-Tsawwassen, Bose-Heron, Whatcom-Scat, and Langley-Cloverdale}

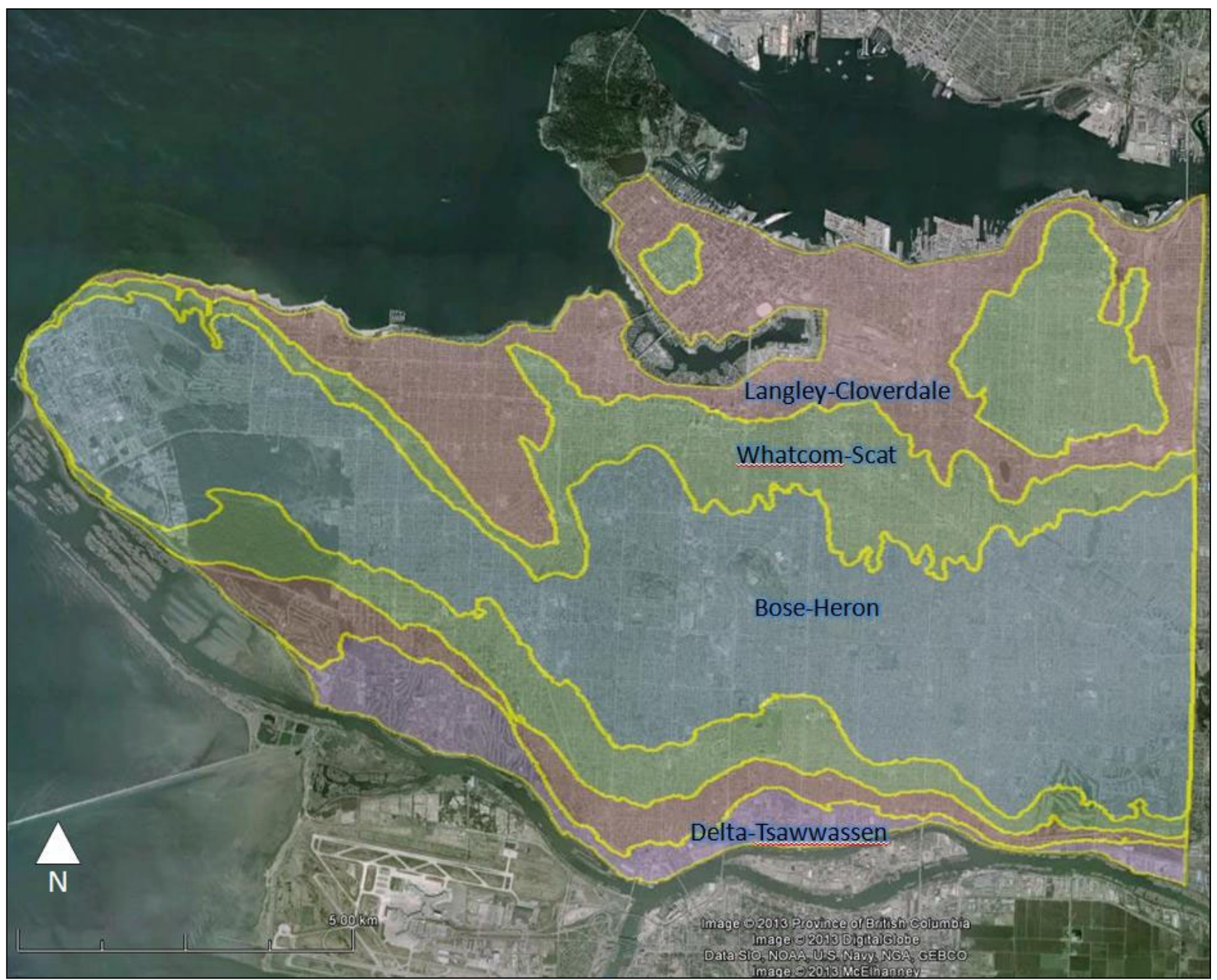

intensity, are often practiced on urban sites (Evans, Fanning, \& Short, 2000). Nonetheless, urban soils can possess some similar properties; those of relevance to Vancouver's soils are shown in Table 2.

One common characteristic of urban soils, particularly those on brownfields, is the probability of soil contamination from sources that are metallic (e.g., cadmium, copper, lead, nickel, or zinc) or organic (e.g., polychlorinated biphenyls or polycyclic aromatic hydrocarbons). To identify these possible hazards, users of Vancouver's SAG are asked to establish the risk level associated with their site. This can be done by determining the past land uses of the site (i.e., the site history). A site history can be obtained by speaking with neighbors, investi- gating the site at the city archives, and observing site artifacts (e.g., litter, remnants of past structures). The SAG provides users with information to help them determine if the site history indicates the possibility of soil contamination. For example, the presence of a Laundromat on the site, neighbor reports of illegal dumping, or large quantities of litter are evidence that a site should be placed in the "high risk" category. If the site history is unclear, or if there are indications that a site might be contaminated, soil sample collection and analysis in a soil-testing laboratory is recommended. Further guidance on soil sampling and interpreting laboratory results is also provided in the SAG. Similar approaches are recommended by Toronto 
Table 3. Properties of the Top Mineral Horizon of the Four Soil Management Groups Encountered within the City of Vancouver, British Columbia

\begin{tabular}{|c|c|c|c|c|}
\hline \multirow[t]{2}{*}{ Property } & \multicolumn{4}{|c|}{ Soil management group } \\
\hline & Bose-Heron & Whatcom-Scat & Langley-Cloverdale & Delta-Tsawwassen \\
\hline Textural class & $\begin{array}{c}\text { Gravelly loamy sand- } \\
\text { loamy sand }\end{array}$ & Silty loam-silty clay & $\begin{array}{l}\text { Silty clay-silty clay } \\
\text { loam }\end{array}$ & $\begin{array}{l}\text { Silty loam-sandy } \\
\text { loam }\end{array}$ \\
\hline Soil reaction $(\mathrm{pH})$ & $5.6-6.1$ & $5.4-5.6$ & $5.6-5.9$ & $4.6-5.6$ \\
\hline Organic carbon (g kg-1) & $9.3-12.8$ & $13.9-50.4$ & $5.0-7.0$ & 7.0 \\
\hline Total nitrogen (g kg-1) & 0.5 & $0.6-2.0$ & $0.5-0.7$ & - \\
\hline $\begin{array}{l}\text { Cation exchange capacity } \\
\left(\mathrm{cmol}_{\mathrm{c}} / \mathrm{kg}\right)\end{array}$ & $17.2-21.3$ & $33.7-46.1$ & $26.3-35.4$ & $16.2-31.5$ \\
\hline $\begin{array}{l}\text { Implications for urban } \\
\text { agriculture }\end{array}$ & $\begin{array}{l}\text { - Moderate capability } \\
\text { for urban agricul- } \\
\text { ture. } \\
\text { - Drainage issues } \\
\text { due to naturally } \\
\text { occurring dense } \\
\text { layer at about } 50 \\
\text { cm depth. Could be } \\
\text { too dry in summer } \\
\text { due to coarse } \\
\text { texture. } \\
\text { - Less able to hold } \\
\text { and release nutri- } \\
\text { ents due to coarse } \\
\text { texture. }\end{array}$ & $\begin{array}{l}\text { - Good capability for } \\
\text { urban agriculture. } \\
\text { Drainage issues } \\
\text { during wet months } \\
\text { due to fine texture. }\end{array}$ & $\begin{array}{l}\text { - Moderate to good } \\
\text { capability for urban } \\
\text { agriculture. } \\
\text { - Drainage issues } \\
\text { during wet months } \\
\text { due to fine texture. } \\
\text { - Susceptible to } \\
\text { compaction. }\end{array}$ & $\begin{array}{l}\text { - Moderate to good } \\
\text { capability for urban } \\
\text { agriculture. } \\
\text { - Drainage issues } \\
\text { during wet months } \\
\text { due to fine texture. } \\
\text { - Susceptible to } \\
\text { compaction. }\end{array}$ \\
\hline
\end{tabular}

Modified after Luttmerding (1984).

Public Health and the U.S. Environmental Protection Agency (EPA) (Toronto Public Health, 2013; U.S. EPA, 2011), both of which provide in-depth resources on detecting soil contamination on land being converted into food-producing gardens.

To convey specific information about Vancouver's soils to community gardeners, a soil map for the city was created (Iverson, Holmes \& Bomke, 2012) (Figure 2). The city of Vancouver is now a member of a very select group of cities worldwide that has a soil map of its urban area. Soil maps of urban areas are rare because many urban centers were developed before a soil inventory was carried out. The Vancouver soil map is composed of four soil management groups, Bose-Heron, WhatcomScat, Langley-Cloverdale, and Delta-Tsawwassen, modeled after the soil management groups for the Lower Fraser Valley (Bertrand, Hughes-Games, \& Nikkel, 1991). Each group is characterized by its own set of properties, summarized in Table 3. These properties are described in detail in the
SAG, outlining the advantages and disadvantages of each group for food production. ${ }^{2}$ Practical suggestions on how to overcome each soil management group's shortcomings are also provided, allowing stakeholders to identify the most suitable management strategy for their garden or farm.

The stakeholder feedback gathered in Phases 2 and 3 allowed us to refine the guide's content and format. Feedback-gathering workshops varied in formality and content depending on the needs and desires of the specific community group. Some workshops adopted a casual question-and-answer format, while others incorporated predetermined topics, informative handouts, and hands-on activities (e.g., a demonstration of soil sampling). Workshop participants provided valuable suggestions about the SAG format. For example, participants

\footnotetext{
2 Further information on the Vancouver soil map and its associated soil management groups can be found at http://www.vancouversoils.ca
} 
at two of the three workshops we conducted indicated that the SAG should include detailed instructions for site observations and soil sampling. They also requested that these instructions be explained using easy-to-understand terminology (i.e., using a limited amount of science-specific vocabulary) and that the number of assessment methods not be too excessive so a person with limited training would be able to complete them in a reasonable time frame.

Common participant-introduced themes at all workshops included properties of urban soils, overview of Vancouver's soils, potential sources of urban soil contamination, logistics of soil sampling and laboratory analyses, and interpretation of soil data. It also become evident that workshop participants shared some similar concerns, and one issue that clearly stood out was the desire to install raised beds, regardless of contamination test results. These concerns were also brought up outside the workshops by the coordinators of two Vancouverbased community gardens. These concerns are consistent with those expressed in studies by De Sousa $(2003,2006)$ carried out in Toronto on real and perceived barriers to greening brownfields. De Sousa (2003) reported that survey participants identified "lack of knowledge about the impacts of soil contamination on human health" as one of the greatest hindrances to reclaiming urban brownfields. Installing raised beds due to perceived soil contamination adds unnecessary cost to garden development and advances the disconnect between urbanites and the native soil. Based on the feedback received during the community workshops, we refined the initial list of selected soil properties by removing those that were too complicated to understand (e.g., cation exchange capacity) or required assessment methods that proved difficult or time-consuming to perform (e.g., earthworm counts).

\section{Use and Reliability of $S A G$}

The SAG can be used by Vancouver's urban agriculture organizations to assess brownfield sites, and can also be used by homeowners, schools, and religious institutions who wish to assess the suitability of their lots for food production. At present, the SAG for Vancouver is made available to these interested parties through the websites of several Vancouver-based environmental organizations, as previously detailed, and is also distributed at workshops and field days as hard copies. Continued efforts are required to make this document more accessible to interested stakeholders and to obtain backing of various groups (the city's parks and health departments, foundations, etc.) to raise awareness of and trust in the SAG.

The SAG is not designed for rigorous data collection that requires total objectivity, precision, and accuracy. Regular annual assessments are still recommended to allow gardeners and urban farmers to monitor soil changes over time. Furthermore, assessments are most reliable when completed by the same person, at the same time of the year, at the same location, and under similar moisture levels (Doran \& Parkin, 1996). The initial assessment for each site becomes a baseline condition that serves as a reference point for future annual assessments that will guide management decisions.

The SAG will allow participants in urban agriculture to conduct site assessments and identify the benefits and barriers of growing food on specific sites in the city and to address these restrictive issues so they will not hinder the success of the farm or garden. In some cases, conversion of a particular site into food production may not be advisable, and efforts and financial resources can therefore be put elsewhere. Moreover, health risks associated with growing food on contaminated land could be avoided. Reclaiming urban sites for community gardens and urban farms is a substantial task, with benefits that affect the larger community. People willing to assume such an undertaking may rely on a SAG to provide guidance, making their goal more easily obtainable.

\section{Conclusions}

Drawing on the principles of soft systems inquiry, community-based action research, and locally led urban environmentalism, we developed the framework for a locally adapted SAG for Vancouver soils. The framework included the following five phases: (1) initial selection of properties and assessment approaches; (2) stakeholder feedback and subsequent revision of the initial list; (3) addi- 
tional feedback, revision, and finalization of the SAG; (4) distribution of the guides; and (5) ongoing updates and support. As part of the framework development, we have identified key site indicators of relevance for Vancouver and developed a soil map of the city with associated soil management groups to provide urban gardeners and farmers with information on key soil properties relevant for food production. Distribution and promotion of the SAG though local organizations and societies started in 2010 and will require ongoing efforts. Vancouver's SAG provides urban agriculturalists with a valuable tool for making informed decisions about the suitability of particular sites for conversion into community gardens and food production. The framework, however, might also be useful to other cities that wish to create their own SAGs and empower their citizens to create spaces for urban agriculture and enjoy the numerous benefits associated with growing food in the city.

\section{Acknowledgments}

This work was supported by the Vancouver Coastal Health Authority and the University of British Columbia, Vancouver. The technical advice and assistance of Dr. Les Lavkulich, Mr. Christian Evans, Dr. Will Valley, and Mr. Chris Thoreau in the field and laboratory are greatly appreciated. We would like to give special thanks to the Cedar Cottage Community Garden, the Environmental Youth Alliance, the Sustainable Living Arts School, Mr. David Tracey, and the city of Vancouver.

\section{References}

Alaimo, K., Packnett, E., Miles, R. A., \& Kruger, D. J. (2008). Fruit and vegetable intake among urban community gardeners. Journal of Nutrition Education and Behavior, 40(2), 94-101. http://dx.doi.org/10.1016/i.jneb.2006.12.003

Alaimo, K., Reischl, T. M., \& Allen, J. O. (2010). Community gardening, neighborhood meetings, and social capital. Journal of Community Psychology, 38(4), 497-514. http://dx.doi.org/10.1002/jcop.20378

Armstrong, J. E., \& Hicock, S. R. (1976). Surficial geology, Vancouver, British Columbia, Map 1486A
[Soil map]. Retrieved from http://geogratis.gc.ca/ api/en/nrcan-rncan/ess-sst/afe5a80d-32ef-50a19491-5e0553576498.html

Bertrand, R. A., Hughes-Games, G. A., \& Nikkel, D. C. (1991). Soil management handbook for the Lower Fraser $V$ alley. Abbotsford, British Columbia, Canada: Soils and Engineering Branch, British Columbia Ministry of Agriculture, Fisheries and Food.

Brown, L. R. (2009). Plan B 4.0: Mobilizing to save civilization. New York: Norton.

Checkland, P., \& Scholes, J. (1999). Soft systems methodology in action. Chichester, West Sussex, England: Wiley.

City of Vancouver. (2013a, December 16). Green Vancouver. Retrieved November 26, 2012, from http://vancouver.ca/green-vancouver/geo.aspx

City of Vancouver. (2013b, December 16). People and programs. Retrieved November 26, 2012, from http://vancouver.ca/people-programs/ community-gardens.aspx

De Kimpe, C. R., \& Morel, J. L. (2000). Urban soil management: A growing concern. Soil Science, 165(1), 31-40. http://dx.doi.org/10.1097/ 00010694-200001000-00005

De Sousa, C. A. (2003). Turning brownfields into green space in the City of Toronto. Landscape and Urban Planning, 62(4), 181-198. http://dx.doi.org/10.1016/S0169-2046(02)00149-4

De Sousa, C. A. (2006). Urban brownfields redevelopment in Canada: The role of local government. The Canadian Geographer, 50(3), 392-407. http://dx.doi. org/10.1111/j.1541-0064.2006.00148.x

Ditzler, C. A., \& Tugel, A. J. (2002). Soil quality field tools. Agronomy Journal, 94(1), 33-38. http://dx.doi.org/10.2134/agronj2002.0033

Doran, J. W., \& Parkin, T. B. (1996). Quantitative indicators of soil quality: A minimum data set. In J. W. Doran \& A. J. Jones, Methods for assessing soil quality (pp. 25-37). Madison, Wisconsin: Soil Science Society of America.

Environment Canada. (2014). National climate data and information archive: Canadian climate normals 1971-2000 station data. Retrieved from http://climate.weather.gc.ca/climate normals/resu lts_e.html?stnID $=889$ \&lang $=e \&$ StationName $=$ Van couver\&SearchType $=$ Contains\&stnNameSubmit $=\mathrm{g}$ o\&dCode $=1$ 
Evans, C. V., Fanning, D. S., \& Short, J. R. (2000). Human-influenced soils. In R. B. Brown, J. H. Huddleston, \& J. L. Anderson (Eds.), Managing soils in an urban environment (pp. 33-67). Madison, Wisconsin: Soil Science Society of America. http://dx.doi.org/10.2134/agronmonogr39.c2

Hazleton, P. \& Murphy, B. (2011). Understanding soils in urban environments. London: Earthscan.

Hynes, H. P., \& Howe, G. (2004). Urban horticulture in the contemporary United States: Personal and community benefits. Proceedings of the International Conference on Urban Horticulture, 643, 171-181.

Iverson, M. A., Holmes, E. P., \& Bomke, A. A. (2012). Development and use of rapid reconnaissance soil inventories for reclamation of urban brownfields: A Vancouver, British Columbia, case study. Canadian Journal of Soil Science, 92(1), 191-201. http://dx.doi.org/10.4141/cjss2010-029

Kaethler, T. M. (2006). Growing space: The potential for urban agriculture in the City of $V$ ancouver. Vancouver, British Columbia: School of Community and Regional Planning, University of British Columbia.

Luttmerding, H. A. (1984). Soils of the Langley-Vancouver map area. Kelowna, British Columbia: British Columbia Ministry of Environment.

Patel, S., \& MacRae, R. (2012). Community supported agriculture in the city: The case of Toronto. Journal of Agriculture, Food Systems, and Community Development, 2(4), 85-100. http://dx.doi.org/10.5304/jafscd.2012.024.003
Romig, D. E., Garlynd, M. J., Harris, R. F., \& McSweeney, K. (1995). How farmers assess soil health and quality. Journal of Soil and Water Conservation, 50(3), 229-236.

Stringer, E. T. (1999). Action research. Thousand Oaks, California: Sage Publications.

Toronto Public Health. (2013). Guide for soil testing in urban gardens. Retrieved from http://www.tcgn.ca/ wiki/uploads/DonationsTradesSharing/TPH Summary JAAv3.pdf

Tugel, A. J., Seiter, S., Friedman, D., Davis, J., Dick, R. P., McGrath, D., \& Weil, R. R. (2001). Locally led conservation activities: Developing a soil quality assessment tool. In D. E. Stott, R. H. Mohtar, \& G. C. Steinhardt (eds.), Sustaining the global farm: Selected papers from the 10th International Soil Conservation Organization Meeting (pp. 529-534). West Lafayette, Indiana: International Soil Conservation Organization.

Turner, B., Henryks, J., \& Pearson, D. (2011). Community gardens: Sustainability, health and inclusion in the city. Local Environment: The International Journal of Justice and Sustainability, 16(6), 489-492.

http://dx.doi.org/10.1080/13549839.2011.595901

U.S. Environmental Protection Agency [EPA]. (2011). Brownfields and urban agriculture: Interim guidelines for safe gardening practices. Retrieved from http://www.epa. gov/brownfields/urbanag/pdf/bf urban ag.pdf 